\title{
Wound healing and antibacterial properties of methanolic extract of Pupalia lappacea Juss in rats
}

\author{
Sunday Ositadinma Udegbunam², Rita ljoema Udegbunam, Chijioke Clement Muogbo², \\ Madubuike Umunna Anyanwu ${ }^{3^{*}}$ and Chinaka Onyebuchi Nwaehujor ${ }^{4}$
}

\begin{abstract}
Background: Wound healing is a natural process that enables tissue repair after an injury. To shorten its duration and minimize associated complications, wounds are treated with medications. Currently there is a growing interest in the use of alternative wound dressing agents such as plant extracts. One plant used traditionally in wound treatment is Pupalia lappacea. In view of its use in wound care, we investigated the wound healing activities of $80 \%$ methanolic leave extract of Pupalia lappacea using excision, incision and dead space wound models. Also its effects on three common wound contaminants were investigated.
\end{abstract}

Methods: Excision wounds were created, contaminated with microbes and treated with ointments (10\% and 20\% $w / W$ ) prepared from Pupalia lappacea. Incision and dead space wounds were also created in rats which were subsequently dosed orally with the extract. The wound healing activities of Pupalia lappacea ointment on excision wound was assessed by rates of wound contraction and epithelialization as well as its antibacterial effects. The effects of Pupalia lappacea on incision and dead-space wounds were determined by the wound breaking strengths and weights of the granuloma tissues formed, respectively.

Results: Pupalia. lappacea ointments significantly $(p<0.05)$ accelerated wound healing with $20 \%$ ointment having the highest percentage wound contraction and rate of epithelialization. At 4, 7 and 14 days post treatment, mean total viable bacterial count of excision wounds of the extract treated groups were significantly $(p<0.05)$ lower compared against the control. Wound breaking strengths and weights of granuloma tissues formed in the extract treated groups were significantly $(p<0.05)$ higher than those of the control group. The minimum inhibitory concentration values obtained for the Pupalia lappacea extract against Pseudomonas aeruginosa, Staphylococcus aureus and Bacillus subtilis were $9 \mathrm{mg} / \mathrm{ml}, 4 \mathrm{mg} / \mathrm{ml}$ and $3 \mathrm{mg} / \mathrm{ml}$, respectively, while the corresponding minimum bactericidal concentrations were $10 \mathrm{mg} / \mathrm{ml}, 8 \mathrm{mg} / \mathrm{ml}$ and $7 \mathrm{mg} / \mathrm{ml}$.

Conclusion: The results obtained showed that Pupalia. lappacea has good wound healing and antibacterial activities. These findings validate the use of this plant in traditional medicine for treatment of wounds.

Keywords: Pupalia lappacea, Wounds, Antibacterial, Ointments

\section{Background}

A wound refers to an injury to the skin or underlying tissues or organs [1]. Dermal wounds are often caused by surgery, trauma, and chemicals or as a result of diseases [1,2]. Intentionally created dermal wounds can be incisional, whereby the wound is brought about by surgical cutting into the skin with a scalpel or excision wound created

\footnotetext{
* Correspondence: onlymadu2010@yahoo.com

${ }^{3}$ Department of Veterinary Pathology and Microbiology, Faculty of Veterinary Medicine, University of Nigeria, Nsukka, Nigeria

Full list of author information is available at the end of the article
}

when a part of the skin is cut off [3]. The process of tissue repair after an insult to the tissue (wound) is called 'wound healing' [4]. Wound healing is an intricate process in which usually the skin repairs itself [5]. The process involves four overlapping phases: haemostasis (ceasation of bleeding), inflammation, proliferation, and remodeling $[4,5]$.

In haemostasis, thromboxane synthase (TXS) converts prostaglandin $\mathrm{H} 2$ into thromboxane $\mathrm{A} 2$ which causes vasoconstriction and platelet aggregation [6]. Failure of the haemostatic process is prevented by plasminogen activator inhibitor type 1 (PAI-1), an inhibitor of fibrinolysis 
[7]. In the inflammation phase, neutrophils release free radicals to kill wound contaminating bacteria $[8,9]$. Heme and heme proteins which accumulate at the local site of the wound have prooxidative and proinflammatory properties by inducing the expression of adhesion molecules, causing vascular permeability and leukocyte infiltration. These actions initiate wound healing process [5]. Conversely, heme oxygenase-1 (HO-1) has anti-inflammatory and antioxidant activities and is responsible for a wide range of wound healing functions. It converts heme into biliverdin/bilirubin, iron and carbon monoxide, which are potent antioxidant products [5]. In proliferation phase, overexpression of HO-1 helps to accelerate wound healing such as amelioration of inflammation, proliferation and protection against endothelial cell apoptosis [10]. In remodeling phase, matrix metalloproteinases (MMPs) plays a major role in wound healing by extracellular matrix (ECM) remodeling [11].

The length of time it takes for wound healing process to be complete is dependent on the rate of availability of biochemical substances required for each phase to occur. To shorten the duration of the healing process and minimize complications (such as overwhelming bacterial wound contamination) of natural healing, medical professionals use orthodox medications (which increase the rate of healing process and/or control secondary microbial wound contamination) to treat wounds [12]. But, the prices of these orthodox medications are exorbitant and many wound contaminating bacteria are becoming increasingly resistant to their effects [13].

In traditional medicine, medicinal plants are used in the preparation of decoctions which are applied to dermal wounds to enable healing [14]. The efficacies of these plants in wound healing have been experienced and passed on from one generation to the other. One of these medicinal plants widely used traditionally in Nsukka Southeast, Nigeria in treating wounds is Pupalia lappacea (Family Amaranthaceae). The common name is forest Burr or creeping cork's comb. It is an erect or straggling under shrub with flowers in spicate clusters, and it usually grows along hedges [13]. It is used in agrihorticulture as a fodder [15]. Traditional practitioners including those in Nsukka, claim that foliage parts of $P$. lappacea are used in form of poultices and decoctions to treat different ailments such as bone fractures and inflammatory conditions, boils, cough, fever, leprosy sores, flatulence, jaundice, abdominal colic, cephalgia, diarrhoea, paralysis, erectile dysfunction, vomiting, toothache, cuts, chronic wounds, fever and malaria [13,16-20]. For the treatment of wounds, the leaf paste and the fruit juice is applied externally [13]. Scientific investigations have validated some of these claims such as antimalaria [20], anticancer [13], antinociceptive and antipyretic [18] activities of the P. lappacea extract. No study has been done to evaluate its wound healing and antibacterial activities.
Moreover, chemical investigations of $P$. lappacea leaf extract revealed that it consists of 8 compounds which included: 1-docosanol, stearic acid, stigmasterol, sitosterol, $\mathrm{N}$-benzoyl-L-phenyl alaninol acetate, setosterol-3-O-Dglucopyranoside, stigmasterol-3-O-D-glucopyranoside and 20-hydroxyl ecdysone [21]. These biochemical compounds have been shown to promote wound healing process in animals and humans. Stigmaesterol have been shown to exhibit haemostatic [22] and anti-inflammatory activities [5,23]. The 20-hydroxyl ecdysyne promoted protein synthesis and wound healing in animals and humans [24]. Docosanol was used by to treat herpes simplex virus cutaneous wounds in mice [25]. Plant extract that contains $\mathrm{N}$-benzoyl-L-phenyl alaninol exhibited antibacterial activity [26]. Since some of the compounds contained in $P$. lappacea leaf extract showed activities involved in wound healing process, the plant extract may exhibit wound healing activities in animals and humans as claimed by the traditional practitioners. The objective of this study was therefore to evaluate the wound healing and antibacterial activities of $P$. lappacea methanolic leaf extract in rats.

\section{Methods}

The experimental protocols used in this study was approved by the Ethics Committee of the University of Nigeria, Nsukka and conforms with the guide to the care and use of animals in research and teaching of University of Nigeria, Nsukka, Enugu State Nigeria.

\section{Animals}

A total of 92 8-week-old male albino Wistar rats weighing between 129 and $131 \mathrm{~g}$ were obtained from the laboratory animal unit, Faculty of Veterinary Medicine, University of Nigeria, Nsukka. They were fed on commercial growers mash (Top feeds ${ }^{\oplus}$ ) and water was provided ad libitum. These rats were acclimatized for 2 weeks in the animal house at the Department of Veterinary Surgery, University of Nigeria, Nsukka.

\section{Plant collection and identification}

Fresh leaves of Pupalia lappacea were collected from Obollo-Afor in Nsukka Local Government Area Enugu State, Nigeria, in the month of March 2013 and were identified at the International Center for Ethnomedicine and Drug Development (InterCEDD), Nsukka, by a plant taxonomist, Mr. A. Ozioko. Samples were registered and deposited in the center's herbarium.

\section{Extraction}

Half a kilogram of the leaves were air dried at room temperature for 2 weeks and then pulverized using the laboratory grinding machine at the Department of Crop Science, University of Nigeria, Nsukka. The pulverized 
leaves were macerated in $80 \%$ methanol for $48 \mathrm{hr}$ with intermittent vigorous shaking at every $2 \mathrm{hr}$. After $48 \mathrm{hr}$, the mixture was filtered and the extract concentrated using a rotary evaporator set at $40^{\circ} \mathrm{C}$. The dried extract was weighed and the percentage yield calculated. The extract was then stored at $4^{\circ} \mathrm{C}$ in a refrigerator before use.

\section{Acute toxicity test}

Thirty adult rats were randomly divided into six groups of five animals per group. The animals were deprived water for $16 \mathrm{hr}$ before administration of the extract. The increasing doses of the extract 200, 400, 600, 1000 and $2000 \mathrm{mg} / \mathrm{kg}$ body weight suspended in dimethylsulfoxide (DMSO) was administered orally to the test groups, respectively, using a ball-tipped intubation needle fitted onto a syringe. The last group received $1 \mathrm{ml} / \mathrm{kg}$ of DMSO and served as the control. The rats were allowed access to food and water ad libitum and were observed for $48 \mathrm{hr}$ for behavioural changes and death. The time of onset, intensity, and duration of these symptoms, if any, was recorded.

\section{Phytochemical analysis for bioactive substances}

The methanolic leaf extract was screened for the presence of bioactive components following the methods of Trease and Evans [27].

\section{Preparation of ointments}

The method of Okore et al. [28] was adopted in preparation of two herbal ointments containing $10 \% \mathrm{w} / \mathrm{w}$ and $20 \% \mathrm{w} / \mathrm{w}$ of the extract in sterile soft white paraffin. Immediately after preparation, the ointments were aseptically transferred into sterile cream tubes and sealed.

\section{Pathogens and preparation of inocula}

The bacterial organisms - Pseudomonas aeruginosa, Stapylococcus aureus and Bacillus subtilis used in this study were collected from the Department of Pharmaceutics, University of Nigeria, Nsukka. They were clinical wound isolates from patients in Nsukka, Nigeria, fully identified and maintained on nutrient agar slope at $4^{\circ} \mathrm{C}$ at the Department of Pharmaceutical Microbiology Laboratory, University of Nigeria, Nsukka. Prior to use, the organisms were sub-cultured on sterile nutrient agar plate, incubated aerobically at $37^{\circ} \mathrm{C}$ for $24 \mathrm{hr}$. Colonies of each organism was homogenized in sterile phosphate buffered saline (PBS) and the turbidity adjusted to correspond to 0.5 McFarland's turbidity standard (equivalent to $1 \times 10^{8} \mathrm{cfu} / \mathrm{ml}$ ). The standardized broth cultures were kept at $4^{\circ} \mathrm{C}$ until needed.

Determination of minimum inhibitory concentration (MIC) and minimum bactericidal concentration (MBC)

MIC of the extract was determined by macro broth dilution following the method described by Baron and Finegold [29]. Dilution of P. lappacea extract was made to various concentrations of $1,2,3,4,5,6,7,8,9$ and $10 \mathrm{mg} / \mathrm{ml}$ in series of test tubes. Equal volume of the extract and sterile nutrient broth were mixed. Specifically, $0.1 \mathrm{ml}$ of standardized inoculum $\left(1 \times 10^{8} \mathrm{cfu} / \mathrm{ml}\right)$ of each of the test organism was added to each tube. The tubes were incubated aerobically at $37^{\circ} \mathrm{C}$ for $24 \mathrm{~h}$. Two control tubes were maintained for each test batch. These included antibiotic control (tube containing extract and the growth medium without inoculum) and organism control (the tube containing the growth medium, physiological saline and the inoculum). The lowest concentration (highest dilution) of the extract that produced no visible bacterial growth (no turbidity) when compared with the control tubes were regarded as MIC. However, the MBC was determined by sub-culturing the test dilution on to a fresh drug-free nutrient agar and incubated further for $24 \mathrm{hr}$. The highest dilution that yielded no single bacterial colony on a solid medium was taken as MBC.

\section{Wound healing studies Creation and contamination of excision wound}

Thirty two rats were anaesthesized with $10 \mathrm{mg} / \mathrm{kg}$ body weight of xylazine hydrochloride and $50 \mathrm{mg} / \mathrm{kg}$ ketamine hydrochloride. Their dorsum was shaved and disinfected with methylated spirit. Then, full thickness excision wounds were created following the method described by Morton and Malone [30].

Post wounding, the rats were randomly assigned into 4 groups of 8 animals per group. Then, using sterile Pasteur pipettes, wound on each animal was contaminated by flooding with $1 \mathrm{ml}$ of standardized broth culture of each test organism. To minimize further microbial contamination of wound, each animal was carefully placed individually in disinfected cages kept in a disinfected, clean and dust-free animal house in the Department of Veterinary Surgery, University of Nigeria, Nsukka. The wounds were not treated for $24 \mathrm{hr}$ post contamination to ensure colonization and establishment of infection. Treatment of animal wound commenced $48 \mathrm{hr}$ post contamination. Four treatment groups consisting of 5 animals per group were treated as follows: groups I and II were treated topically with $20 \%$ and $10 \%$ P. lappacea leaf extract ointment (PLLEO), respectively, while groups III and IV were treated with gentamicin sulphate and sterile soft white paraffin, respectively. Treatment of the animals continued until complete healing occurred.

\section{Percentage wound contraction}

The wound diameter of each animal was measured at $7,10,13,16,19,21,24$ and 27 days post wounding (dpw) using a transparent meter rule, and the percentage wound contraction calculated using the method of Ezike et al. [31]. 


\section{Wound epithelialization}

Period of wound epithelialization was calculated as the number of days required for the scar to fall off leaving no raw wound [32]. The mean days for wound epithelialization for each group were calculated.

\section{Determination of wound microbial load}

At 4, 7 and 14 days post-treatment (dpt), wound swabs from each animal was taken in duplicate using sterile swab sticks. The total viable count of the wound was determined following the standard plate counting method [33]. Briefly, each swab was inoculated into sterile nutrient broth to make stock solutions which was used for doublefold $\left(10^{-2}\right)$ dilutions. Using a sterile pipette, $0.1 \mathrm{ml}$ of the $10^{-2}$ dilution was introduced on the surface of sterile nutrient agar and a sterile glass spreader was used for even distribution of the inoculum. The inoculated plates were incubated at $37^{\circ} \mathrm{C}$ for 24 hours and the colonies were counted using a colony counter.

\section{Incision wound}

The method of Rathi et al. [34] was adopted. Fifteen rats were anaesthetized with $10 \mathrm{mg} / \mathrm{kg}$ body weight of xylazine hydrochloride and $50 \mathrm{mg} / \mathrm{kg}$ ketamine hydrochloride. Their dorsum was prepared for aseptic surgery. Then, paravertebral $(5 \mathrm{~cm})$ full thickness skin incisions were made on the animals using sterile scalpel blade. The incisions were sutured using size $2 / 0$ silk thread with sterile swaged-on traumatic needle. Three treatment groups consisting of 5 animals per group were treated as follows: groups A and B were dosed orally with $300 \mathrm{mg} / \mathrm{kg}$ of $20 \%$ and $10 \%$ of the extract, respectively, while group $C$ was given $1 \mathrm{ml} / \mathrm{kg}$ of sterile normal saline. The animals were treated daily for a period of 7 days. Sutures were removed at 8 $\mathrm{dpw}$, and the wound breaking strength determined at 10 dpw using the constant water flow technique [35].

\section{Dead space wound}

Dead space wound were created following the method described by Rathi et al. [34]. Fifteen rats were randomly assigned into 3 groups of 5 animals per group. Under general anaesthesia (achieved using $10 \mathrm{mg} / \mathrm{kg}$ body weight of xylazine hydrochloride and $50 \mathrm{mg} / \mathrm{kg}$ ketamine hydrochloride), subcutaneous dead space wound were created in the region of the axilla by making a pouch through a small nip in the skin. Granuloma formation was induced by implanting sterile cotton pellets $(30 \mathrm{mg})$ one on each axillae. The wounds were sutured and mopped with alcoholic swab. The animals were placed individually in a metal cage after grouping them to avoid them biting each other's wound. Groups D and E were administered orally with $300 \mathrm{mg} / \mathrm{kg}$ of $20 \%$ and $10 \%$ of the extract, respectively, while group $\mathrm{F}$ was given $1 \mathrm{ml} / \mathrm{kg}$ of sterile normal saline, for 8 days. At day 10, rats were euthanatized and the cotton pellets together with the granuloma tissues were carefully removed, dried in the oven at $60^{\circ} \mathrm{C}$, weighed and compared with the control.

\section{Statistical analysis}

The data obtained were analysed using one way analysis of variance (ANOVA) and a value of $\mathrm{p}<0.05$ was considered significant.

\section{Results}

\section{Extraction}

The methanolic leaf extract of P. lappacea had an aromatic smell and was greenish-black in colour. The percentage yield was $13.5 \% \mathrm{w} / \mathrm{w}$ material.

\section{Acute toxicity test}

Administration of methanolic leaf extract of $P$. lappacea suspended in DMSO to rats even at the highest dose of $2000 \mathrm{mg} / \mathrm{kg}$ did not produce any death in the treated groups. No sign of acute toxicity was also observed.

\section{Phytochemical analysis}

Preliminary phytochemical analysis qualitatively revealed the presence of steroids, glycosides, saponins, flavonoids, alkaloids, sugar and phenol. These were ascertained from the reactions involving colour changes, haemolysis, turbidity, layers, emulsification and precipitation (Table 1).

\section{Minimum inhibitory and bactericidal concentrations of $P$. lappacea extract on wound isolates}

The MIC values obtained for the $P$. lappacea extract against $P$. aeruginosa, $S$. aureus and B. subtilis was $9 \mathrm{mg} /$ $\mathrm{ml}, 4 \mathrm{mg} / \mathrm{ml}$ and $3 \mathrm{mg} / \mathrm{ml}$, respectively, while the corresponding $\mathrm{MBC}$ were $10 \mathrm{mg} / \mathrm{ml}, 8 \mathrm{mg} / \mathrm{ml}$ and $7 \mathrm{mg} / \mathrm{ml}$, respectively (Table 2).

\section{Wound contraction}

The percentage wound contraction in group I (20\% extract treated) at $7 \mathrm{dpw}$ was significantly $(\mathrm{p}<0.05)$ high compared to groups II (10\% extract treated), III (gentamicin treated) and IV (soft white paraffin treated). At 16,

\section{Table 1 Phytochemical analysis of $P$. lappacea extract}

\begin{tabular}{ll}
\hline Phytoconstituent & Amount \\
\hline Steroids & +++ \\
Glycosides & +++ \\
Saponins & ++ \\
Alkaloids & +++ \\
Sugar & ++ \\
Phenol & + \\
Tannins & - \\
\hline
\end{tabular}

Keys: $+++=$ appreciable amount, $++=$ moderate amount, $+=$ trace amount $-=$ completely absent. 
Table 2 Minimum inhibitory and bactericidal concentrations of $P$. lappacea extract on tested bacterial organisms

\begin{tabular}{lll}
\hline Bacterial organism & MIC $(\mathbf{m g} / \mathbf{m l})$ & MBC $(\mathbf{m g} / \mathbf{m l})$ \\
\hline Pseudomonas aeruginosa & 9 & 10 \\
Staphylococcus aureus & 4 & 8 \\
Bacillus subtilis & 3 & 7
\end{tabular}

Key: $\mathrm{mg} / \mathrm{ml}$, milligram per millilitre.

19 and $21 \mathrm{dpw}$, though the percentage wound contraction in group I was the highest, it was not statistically significant $(p>0.05)$ compared to that of group III, but the percentage wound contraction of animals in groups I and III were significantly $(\mathrm{p}<0.05)$ higher than those in groups II and IV. Animals in group IV showed significantly $(\mathrm{p}<0.05)$ the least contraction rate throughout the study period. For all groups, most wound contraction occurred between 7 and $21 \mathrm{dpw}$ (Table 3).

\section{Wound epithelialization}

Epithelialization occurred between 18 and $25 \mathrm{dpw}$ (Table 4). Epithelialization was significantly $(\mathrm{p}<0.05)$ faster in animals in group I compared with those in groups II and IV. There was no significant difference $(p>0.05)$ in epithelialization time of wound between animals in groups I and III.

\section{Wound bacterial load}

At $4 \mathrm{dpt}$, mean total viable count obtained in the treated groups (I, II and III) were significantly $(\mathrm{p}<0.05)$ lower compared against the untreated control. Similar trend was observed at 7 and 14 dpt (Table 5).

\section{Incision wound}

The wound breaking strength results showed a significant $(\mathrm{p}<0.05)$ increase in the healed wounded tissue in groups $\mathrm{A}$ and $\mathrm{B}$ (extract treated) when compared against the control (Table 6).

\section{Dead space wound}

The result of the effect of the methanolic leaf extract of P. lappacea on granuloma weight showed that the weight of granuloma tissue of animals in group D (300 mg/kg of
$20 \%$ extract treated) was significantly $(\mathrm{p}<0.05)$ higher than those in groups $\mathrm{E}$ and $\mathrm{F}$ (control) (Table 7).

\section{Discussion}

Wound healing according to Al-Henhena et al. [36] is a complex and dynamic process by which cellular structures and tissue layers in a damaged tissue restores itself as closely as possible to its original state. Wound contraction begins a week post wounding at the fibroblastic stage with the wound area undergoing shrinkage [36,37]. In the present study, topical application of $P$. lappaceae extract significantly accelerated wound healing with $20 \%$ ointment having the highest percentage wound contraction ability followed by gentamicin (a commercially sold antimicrobial agent used in dressing wounds) and $10 \%$ ointment of $P$. lapeacae. Wound contraction is made possible either due to an enhanced activity of fibroblast in regenerated wound tissue [38]. Myofibroblasts are believed to play a key role in wound contraction by exerting tension on surrounding extracellular matrix and secreting collagen which stabilizes the contraction [39]. The contracture potency of wounds might also be due to the ability of the wound dressing agents to enhance the synthesis in addition to collagen, fibronectin transforming growth factor BI [40]. There is also a report on increase levels of hexosamine and uric acid (matrix molecules) during early stage of wound healing [41]. In view of the above reports, the wound contraction and healing effects of $P$. lappacea might be attributed to its ability to stimulate and increase the synthesis of one or more of the above mentioned cells and substances/ factors known to promote wound healing.

Stimulation of epithelial cell proliferations and angiogenesis are vital for wound healing process to take place [42]. Wound epithelialization is a process whereby there is epithelial regeneration post wounding with the epithelial cells proliferating and migrating over the wound bed, thereby providing a protective cover for the freshly formed tissues [43]. P. lapaceae extract might have accelerated epithelial regeneration due to its ability to promote angiogenesis and collagen formation and depositions [44,45]. According to Cohen et al. [46], collagen is a principal component of connective tissue and provides a structural framework for the regenerating tissue. Angiogenesis in

Table 3 Percentage wound contraction in rats post infliction of excision wounds

\begin{tabular}{|c|c|c|c|c|c|c|c|c|}
\hline \multirow[t]{2}{*}{ Group (Treatment) } & \multicolumn{8}{|c|}{ Mean \pm standard error of mean wound contraction at days post wounding } \\
\hline & 7 & 10 & 13 & 16 & 19 & 21 & 24 & 27 \\
\hline I (20\% PLLEO) & $18.0 \pm 3.5^{a}$ & $35.6 \pm 5.3$ & $35.7 \pm 6.8$ & $39.9 \pm 0.7^{a}$ & $70.2 \pm 13.4^{a}$ & $79.9 \pm 13.4^{a}$ & $100 \pm 0.0^{a}$ & $100.0 \pm 0.0^{\mathrm{a}}$ \\
\hline \| (10\% PLLEO) & $8.1 \pm 1.2^{b}$ & $39.8 \pm 2.2$ & $22.6 \pm 2.8$ & $22.9 \pm 4.3^{b}$ & $35.7 \pm 5.8^{b}$ & $44.2 \pm 7.4^{b}$ & $89.0 \pm 1.0^{\mathrm{a}}$ & $100.0 \pm 0.0^{\mathrm{a}}$ \\
\hline III (Gentamicin ointment) & $7.9 \pm 1.5^{b c}$ & $36.7 \pm 6.8$ & $26.8 \pm 5.4$ & $36.7 \pm 8.0^{\mathrm{a}}$ & $63.3 \pm 15.4^{\mathrm{a}}$ & $70.9 \pm 13.0^{\mathrm{a}}$ & $100.0 \pm 0.0^{\mathrm{a}}$ & $100.0 \pm 0.0^{\mathrm{a}}$ \\
\hline IV (Normal saline) & $8.7 \pm 3.0^{\mathrm{bd}}$ & $25.4 \pm 4.6$ & $23.3 \pm 5.4$ & $21.0 \pm 4.9^{c}$ & $22.4 \pm 5.7^{c}$ & $47.8 \pm 14.8^{b}$ & $65.1 \pm 10.4^{b}$ & $87.0 \pm 8.3^{b}$ \\
\hline
\end{tabular}

Key: PLLEO = Pupalia lappacea leaf extract ointment.

Different superscripts ${ }^{a, b, c, d}$ across a column indicate significant difference in means at $p<0.05$. 
Table 4 Epithelialization time of rats post infliction of excision wound

\begin{tabular}{ll}
\hline Group (Treatment) & $\begin{array}{c}\text { Mean } \pm \text { standard error of mean } \\
\text { epithelialization time (days) }\end{array}$ \\
\hline I (20\% PLLEO) & $18.6 \pm 0.5^{\mathrm{a}}$ \\
II (10\% PLLEO) & $22.0 \pm 0.1^{\mathrm{b}}$ \\
III (Gentamicin ointment) & $19.6 \pm 0.3^{\mathrm{a}}$ \\
IV (Normal saline) & $25.2 \pm 0.2^{\mathrm{b}}$ \\
\hline
\end{tabular}

Key: $P L L E O=$ Pupalia lappacea leaf extract ointment.

Different superscripts ${ }^{a, b}$ across a column indicate significant difference in means at $\mathrm{p}<0.05$

granulation tissues on the other hand improves circulation to the wound site thereby providing oxygen and nutrients necessary for healing process that include reepithelialization [47].

Wound tensile strength which is one of the indices for assessing wound healing is determined by the amount of fibroblast proliferation, collagen synthesis and neovascularization [38]. In this study, two models viz incisional and dead space wound were used to assess the effect of the methanolic leaf extract of Pupalia lappaceae on the tensile strength of the healed tissues. According to Kumar et al. [48], collagen which principally strengthens the wound and support extracellular tissue is composed of amino acids. Nayak et al. [32] also documented that the increase in the granuloma weight is associated with the presence of high content of protein. The pro-healing property of the extract by these facts might be attributed to its ability to promote protein synthesis leading to increase in the tensile strength. This ability to promote protein synthesis was dose dependent since the group that received 20\% extract did better than the group that was given $10 \%$ of the extract. Although the mechanism of the increase in the tensile strength was not investigated in this study, the increased tensile strength could further be attributed to the ability of the extract to increase the Van der waals force interaction among the hydrogen ion bonds of the tripled helix collagen, leading to twisting of the collagen fibers [47]. The more the twisting of these collagen

Table 5 Total viable bacterial cell population from excision wounds of rats

\begin{tabular}{llll}
\hline Group (Treatment) & \multicolumn{3}{c}{$\begin{array}{c}\text { Mean } \pm \text { standard error of mean total } \\
\text { viable count at days post-treatment }\end{array}$} \\
\cline { 2 - 4 } & $\mathbf{4}$ & $\mathbf{7}$ & $\mathbf{1 4}$ \\
\hline I (20\% PLLEO) & $5.00 \pm 79^{\mathrm{a}}$ & $4.50 \pm 87^{\mathrm{a}}$ & $0.30 \pm 20^{\mathrm{a}}$ \\
II (10\% PLLEO) & $6.00 \pm 1.40^{\mathrm{a}}$ & $3.80 \pm 0.41^{\mathrm{a}}$ & $0.70 \pm 0.25^{\mathrm{a}}$ \\
III (Gentamicin ointment) & $6.30 \pm 1.46^{\mathrm{a}}$ & $4.20 \pm 2.28^{\mathrm{a}}$ & $0.80 \pm 0.44^{\mathrm{a}}$ \\
IV (Normal saline) & $17.90 \pm 2.76^{\mathrm{b}}$ & $6.10 \pm 1.62^{\mathrm{b}}$ & $1.40 \pm 0.33^{\mathrm{b}}$ \\
\hline
\end{tabular}

Key: PLLEO = Pupalia lappacea leaf extract ointment.

Different superscript ${ }^{a, b}$ across a column indicate significant difference in means at $\mathrm{p}<0.05$
Table 6 Wound breaking strength post infliction of incision wound

\begin{tabular}{lc}
\hline Group (Treatment) & $\begin{array}{c}\text { Mean } \pm \text { standard error of mean } \\
\text { wound breaking strength }\end{array}$ \\
\hline A (300 mg/kg of 20\% PLLE) & $813.8 \pm 57.2^{\mathrm{a}}$ \\
B (300 mg/kg of 10\% PLLE) & $754.3 \pm 62.5^{\mathrm{a}}$ \\
C (Control) & $478.8 \pm 19.1^{\mathrm{b}}$ \\
\hline
\end{tabular}

Key: $P P L E=P$. lapaccea leaf extract.

Different superscripts ${ }^{\mathrm{a}, \mathrm{b}}$ across a column indicate significant difference in means at $\mathrm{p}<0.05$.

fibers, the greater the tensile strength and invariably the better healing of wounds [47].

The significant decreases in wound bacterial load in the treated groups suggest that the extract has in vivo antibacterial effect against the tested microorganisms which are involved in wound contamination. The extract was able to reduce wound bacterial load comparable to the reference drug, gentamicin. The antibacterial activity of the extract is further supported by the MIC result which showed that $P$. lappacea leaf methanolic extract exhibited bacteriostatic activity against the organisms at the concentrations shown in Table 2. The corresponding MBCs of $10 \mathrm{mg}$, $8 \mathrm{mg} / \mathrm{ml}$ and $7 \mathrm{mg} / \mathrm{ml}$, respectively, further suggest that the extract was bacteriostatic at lower concentrations but bactericidal at higher concentrations.

The understanding and control of microbial infection of wounds is very important for better healing and its management [49]. Post operative wounds are usually infected by bacterial organisms [50]. Signs of bacterial infection of wounds are restlessness and scratching/biting of wound site [36]. Other signs include delay in the onset of the proliferative and remodeling phases of wound healing process due to the release of free radical and lytic enzymes at the wound site [51]. The delay in the wound healing by these free radicals is achieved by the ability of the free radical to destroy the lipids, proteins and extracellular matrix [52]. The absence of irritation and/or pain at wound site during treatment and the significant increase in the rate of wound contraction and wound re-epithelialization is a reflection of good antibacterial potentials of the plant as contained in the in vivo and in vitro antibacterial assay results. The antibacterial activity exhibited by the P. lappacea leaf

Table 7 Mean granuloma weight post infliction of dead space wounds

\begin{tabular}{ll}
\hline Group (Treatment) & $\begin{array}{l}\text { Mean } \pm \text { standard error of } \\
\text { mean granuloma weight }\end{array}$ \\
\hline $\mathrm{D}(300 \mathrm{mg} / \mathrm{kg}$ of $20 \%$ PLLE) & $74.0 \pm 4.3^{\mathrm{b}}$ \\
$\mathrm{E}(300 \mathrm{mg} / \mathrm{kg}$ of $10 \%$ PLLE) & $70.8 \pm 1.8^{\mathrm{a}}$ \\
$\mathrm{F}($ Control) & $70.8 \pm 1.8^{\mathrm{a}}$
\end{tabular}

Key: PLLE = P. lapaccea leaf extract.

Different superscript ${ }^{a, b}$ across a column indicate significant difference in means at $p<0.05$. 
extract could be attributed to its good antioxidant property and pytochemical constituents [53]. In this study, phytochemical analysis showed that $P$. lappacea methanolic leaf extract contained flavonoids, and flavonoids isolated from medicinal plants have been shown to possess antimicrobial activities [54]. Antioxidants have been reported to play a significant role in wound healing process by protecting tissues from oxidative damage [55]. It has been documented that plants with antibacterial and antioxidant properties enhance wound healing by accelerating wound contraction and re-epithelialization $[31,52,56]$.

\section{Conclusion}

The methanolic leaf extract of Pupalia lappacea showed remarkable dose dependent effect on wound contraction, wound epithelialization and wound tensile strength. The antibacterial studies showed that the plant exhibited good in vivo and in vitro antibacterial effects. These results validate the use of this plant in folkloric medicine for the treatment of wounds.

\section{Competing interests}

The authors declare that they have no competing interests.

\section{Authors' contributions}

SOU: Conceived the study, designed, coordinated, carried out the extraction, reconstituted the extract, helped in wound creation and drafting of the manuscript. RIU: Anaesthetized the animals, participated in wound creation and helped in drafting the manuscript. JCM: Sourced the microorganisms, infected the animals, carried out the wound TVC, determined the MIC and MBC of the extract, and helped in drafting the manuscript. MUA: Helped in drafting the manuscript. CON: Carried out the phytochemical analysis of the extract. All authors read and approved the final manuscript.

\section{Acknowledgements}

The authors are grateful to Mr. Alfred Ozioko of International Centre for Drug Development (InterCEDD) Nsukka, Enugu State, Nigeria, for authentication of plant sample.

\section{Author details}

'Department of Veterinary Surgery, Faculty of Veterinary Medicine, University of Nigeria, Nsukka, Nigeria. ${ }^{2}$ Department of Pharmaceutics, Faculty of Pharmaceutical Sciences, University of Nigeria, Nsukka, Nigeria. ${ }^{3}$ Department of Veterinary Pathology and Microbiology, Faculty of Veterinary Medicine, University of Nigeria, Nsukka, Nigeria. ${ }^{4}$ Department of Biochemistry, Faculty of Basic Medical Sciences, University of Calabar, Calabar, Nigeria.

Received: 25 November 2013 Accepted: 29 April 2014

Published: 13 May 2014

\section{References}

1. Agyare C, Dwobeng AS, Agyepong N, Boakye YD, Mensah KB, Ayande PG, Adarkwa-Yiadom M: Antimicrobial, antioxidant, and wound healing properties of Kigelia africana (Lam.) Beneth. and Strophanthus hispidus DC. Adv Pharmacol Sci 2013, http://dx.doi.org/10.1155/2013/692613.

2. Raina R, Prawezi $S$, Verma PK, Pankaj NK: Medicinal plants and their role in wound healing. Vet Scand 2008, 3:1-7.

3. Waldron DR, Trevor P: Management of superficial skin wounds. In Textbook of small animal surgery volume 1. Edited by Slater D. Philadelphia: W. B. Saunders Company; 1993:269.

4. Nguyen DT, Orgill DP, Murphy GF: The pathophysiologic basis for wound healing and cutaneous regeneration, Biomaterials for treating skin loss. Cambridge/Boca Raton: Wood Head Publishing (UK/Europe) and CRC Press (US); 2009:25-57.
5. Pandith H, Zhang X, Liggett J, Min K-Y, Gritsanapan W, Baek SJ: Hemostatic and wound healing properties of Chromolaena odorata leaf extract. ISRN Dermatol 2013, http://dx.doi.org/10.1155/2013/168269.

6. Vezza R, Mezzasoma AM, Venditti G, Gresele P: Prostaglandin endoperoxides and thromboxane $\mathrm{A} 2$ activate the same receptor isoforms in human platelets. Thromb Haemost 2002, 87(1):114-121.

7. Aso Y: Plasminogen activator inhibitor (PAI)-1 in vascular inflammation and thrombosis. Front Biosci 2007, 12(8):2957-2966.

8. Martin P, Leibovich SJ: Inflammatory cells during wound repair: the good, the bad and the ugly. Trends Cell Biol 2005, 15(11):599-607.

9. Fialkow $L$, Wang $Y$, Downey GP: Reactive oxygen and nitrogen species as signaling molecules regulating neutrophil function. Free Radical Biol Med 2007, 42(2):153-164.

10. Wagener FADTG, van Beurden HE, von den Hoff GW, Adema GJ, Figdor CG: The heme-heme oxygenase system: a molecular switch in wound healing. Blood 2003, 102(2):521-528.

11. Stamenkovic $\mathrm{I}$ : Extracellular matrix remodelling: the role of matrix metalloproteinases. J Pathol 2003, 200(4):448-464.

12. Myers KA, Marshal RD, Friedin J: Principles of Pathology in Surgery $1^{\text {st }}$ edition. London: Blackwell Scientific Publications; 1980:58-82.

13. Ravi A, Alvala M, Sama V, Kalle AM, Irlapati VK, Reddy BM: Anticancer activity of Pupalia lappacea on chronic myeloid leukemia K562 cells. DARU J Pharm Sci 2012, 20:86.

14. Udegbunam SO, Nnaji TO, Udegbunam Rl, Okafor JC, Agbo I: Evaluation of herbal ointment formulation of Milicia excelsa (Welw) C.C berg for wound healing. Afr J Biotechnol 2013, 12(21):3351-3359.

15. Burkill HM: The useful plants of west tropical Africa. Kew Publishing; 1985:1:1

16. Rao PP, Reddy RP: A note on folklore treatment of bone fracture from Ranga Reddy District, Andhra Pradesh. Ethnobotany 1999, 11:107-108.

17. Reddy SC, Reddy KN, Murthy EN, Raju US: Traditional medicinal plants used in Seshachalam Hills, Andhra Pradesh, India. J Med Plants Res 2009, 3:408-412.

18. Neeharika V, Fatima H, Reddy BM: Evaluation of antinociceptive and antipyretic effect of Pupalia lappacea Juss. Int Curr Pharm J 2013, 2(2):23-28.

19. Ndjonka D, Agyare C, Luersen $K$, Hensel A, Liebau E: In vitro antileishmanial activity of traditional medicinal plants from Cameroon and Ghana. Int J Pharm 2010, 6:863-871.

20. Bero J, Ganfon H, Jonville MC, Frederich M, Gbaguidi F, DeMol P, Moudachirou M, Quetin-Leclercq J: In vitro antiplasmodial activity of plants used in Benin in traditional medicine to treat malaria. J Ethnopharmacol 2009, 122:439-444.

21. Felix AA, Domingo O: Antioxidant activity and chemical constituents of P. lappacea (L) Juss. Res J Biol Sci 2008, 3:783-785.

22. Triratana T, Suwannuraks $R$, Naengchomnong W: Effect of eupatorium odoratum on blood coagulation. J Med Assoc Thai 1991, 74(5):283-287.

23. Gabay O, Sanchez C, Salvat C, Chevy F, Breton M, Nourissat G, Wolf C, Jacques C, Berenbaum F: Stigmasterol: a phytosterol with potential anti-osteoarthritic properties. Osteoarthritis Cartilage 2010, 18(1):106-116.

24. Lafont R, Dinan L: Practical uses for ecdysteroids in mammals including humans: an update. J Insect Sci 2003, 3(7):1-30.

25. MCKeough MB, Spruance SL: Comparison of new treatment of Herpes labialis. Arch Dermatol 2001, 137:1153-1159.

26. Bobby MN, Wesely EG, Johnson MA: In vitro antibacterial activity of leaves extracts of Albizia lebbeck Benth against some selected pathogens. Asia-Pac Tropl Biomed 2012, doi:10.1016/S2221-1691(12)60324-4.

27. Trease EC, Evans WC: Pharmacognosy. 12th edition. London: Bailliere and Tindall; 1983:115-625.

28. Okore VC, Ibezim EC, Adikwu MU, Attama AA, Esimone CO, Uzuegbu BD, Ofokansi KC: Laboratory techniques in Pharmaceutics and Pharmaceutical Microbiology. 2nd edition. El'Demark Publishers; 2004:1-20.

29. Baron JE, Finegold SM: Method for testing antimicrobial effectiveness. In Bailey Scott's Diagnostic Microbiology. 8th edition. Edited by Mosby CV. Missouri: C. V. Mosby Company; 1990:21-23.

30. Morton JJ, Malone MM: Evaluation of vulnerary activity by open wound procedure in rats. J Trauma 1992, 20(4):323-324.

31. Ezike AC, Akah PA, Okoli CO, Udegbunam S, Okuma N, Okeke C, lloani O: Medicinal plants used in wound care: a study of Prosopis africana (Fabaceae) stem bark. Indian Pharm Sci 2010, 72(3):334-338.

32. Nayak S, Nalabothu P, Sandiford S, Rhogdi V, Adogwa A: Evaluation of wound healing activity of Allamanda cathartica. L. and Laurus nobilis, L. extracts on rats. BMC Complement Altern Med 2006, 6:12. 
33. Clinical and Laboratory Standards Institute (CLSI): Methods for dilution of antimicrobial susceptibility tests for bacteria that grow aerobically, approved standard. 7th edition. Wayne, Pa: Clinical and Laboratory Standards Institute document M7-A7; Clinical and Laboratory Standards Institute; 2006. 5-22.

34. Rathi B, Patil PA, Baheti AM: Evaluation of aqueous extract and seeds of Moringa oleifera for wound healing in albino rats. J Nat Remedies 2004, 4(2):145-149.

35. Lee KH: Studies on mechanism of action of salicylates. retardation of wound healing by aspirin. J Pharm Sci 1986, 51(6):1042-1043.

36. Al-Henhena N, Mahmoood AA, Al-Magrami A, Nor SAB, Zahra AA, Summaya MD, Suzi MS, Salmah I: Histological study of wound healing potential by ethanol leaf extract of Strobilanthes crispus in rats. J Med Plants Res 2011, 5(16):3666-3669.

37. Mohan H: Inflammation and healing. In Textbook of Pathology. 5th edition New Delhi: Jaypee Brothers; 2005:133-179.

38. Habibipour S, Oswald TM, Zhang F, Joshi P, Zhou XC, Dorsett MW Lineaweaver WC: Effects of sodium diphenhydantion on skin wound healing in rats. Plast Reconstr Surg 2003, 2003(112):1620-1627.

39. Suntar IP, Koca U, Esra KA, Yilmazer D, Alper M: Assessment of wound healing activity of the aqueous extracts of Colutea cilicica fruits and leaves Boiss and Bal. Evid Based Altern Complement Med 2011, 2011:1-7.

40. Akkol ES, Koco U, Pesin L, Yilmazer D: Exploring the wound healing activity of Amebia densiflora. J Ethnopharmacol 2009, 124:137-141.

41. Suguna L, Singh S, SivaKumar P, Sampath P, Chandrakason G: Influence of terminalia chebula on dermal wound healing in rats. Phytother Res 2002, 16:227-231.

42. Buntrock $P$, Jentzsch KD, Heder G: Stimulation of wound healing using brain extract with fibroblast growth factor (FGF) activity II. histological and morphometric examination of cells and capillaries. Exp Pathol 1982, 21(1):62-67.

43. Cotran RS, Kumar V, Robbins SL, Schoem FJ: Inflammation and repair. In Robbins Pathologic Basis of Diseases. 5th edition. Pennsylvania: W. B. Saunders Company; 1994:51-92.

44. Trabucchi E, Preis BF, Barathi C, Montorisi W: Topical treatment of experimental skin lesions in rats macroscopic, microscopic and scanning electron microscopic evaluation of the healing process. Int I Tissue React 1986, 8:533-544.

45. Shukla A, Rasik AM, Dhawan RN: Asiaticoside-induced elevation of antioxidant levels in healing wounds. Phytother Res 1999, 13(1):50-54.

46. Cohen IK, Diegelmann RF, Lindblad WJ: Wound healing: Biochemical and Clinical Aspects. Philadelphia: W.B. Saunders Company; 1992:344-355.

47. Szabo S, Kusstatsher S, Sakoulas S, Sandor Z, Vincse A, Jadus M: Growth factors: new endogenous drug for ulcer healing. Scand J Gastroenterol 1995, 210:15-18.

48. Kumar MS, Sripriya R, Raghavan HV, Sehgal PK: Wound healing potential of Cassia fistula on infected albino rat model. J Surg Res 2006, 131:283-289.

49. Muhammad HS, Muhammad S: The use of Lawsonia inermis Linn. (henna) in the management of burn wound infections. Afr J Biotechnol 2005, 4:934-937.

50. Deshmukh PT, Fernandes J, Atul A, Toppo E: Wound healing activity of calotropis gigantean root bark in rats. J Ethnopharmacol 2009, 125:178-181.

51. Eming SA, Werner S, Bugnon P, Wicksiewe L, Utermohien O, Davidson JM, Krieg T, Roers A: Accelerated wound closure in mice deficient for interleukin-10. Am J Pathol 2007, 170(1):170-202.

52. Calabresse V, Scapagnini C, Catalano C, Dinotta F, Geraci D, Morganti P: Biochemical studies of a natural antioxidant isolated from Rosemary and its application in cosmetic dermatology. Int J Tissue React 2000, 22:5-13.

53. Aladedunye AF, Okorie DA: Antioxidant activity and chemical constituents of Pupalia Lappacea (L.) Juss. Res J Biol Sci 2008, 3(7):783-785.
54. Karou D, Savadogo A, Canini A, Yameogo S, Montesano C: Antibacterial activity from Sida acuta. Afr J Biotechnol 2006, 5(2):195-200.

55. Martin A: The use of antioxidants in wound healing. Dermatol Surg 1996 22:156-160

56. Okoli CO, Akah PA, Okoli AS: Potentials of leaves of Aspillia africana (composition) in wound care: an experimental evaluation. BMC Complement Altern Med 2007, 7:24.

doi:10.1186/1472-6882-14-157

Cite this article as: Udegbunam et al:: Wound healing and antibacterial properties of methanolic extract of Pupalia lappacea Juss in rats. BMC Complementary and Alternative Medicine 2014 14:157.

\section{Submit your next manuscript to BioMed Central and take full advantage of:}

- Convenient online submission

- Thorough peer review

- No space constraints or color figure charges

- Immediate publication on acceptance

- Inclusion in PubMed, CAS, Scopus and Google Scholar

- Research which is freely available for redistribution

Submit your manuscript at www.biomedcentral.com/submit
C) BioMed Central 